\title{
Astronomy Outreach
}

\section{Julieta Fierro ${ }^{1}$}

Instituto de Astronomía UNAMn

E-mail: julieta@astroscu.unam.mx

The International Year of Astronomy offers us a unique chance to carry out outreach projects in great scale and, to think about new ways to improve our efforts. In this paper I present a few considerations on my activity as a popularization person. I shall address outreach importance and I will emphasize on public lectures. I will also stress certain ingredients I believe popularization must include: be interesting, diverse, simple, pertinent, and be peer reviewed.

Accelerating the Rate of Astronomical Discovery - sps5

Rio de Janeiro, Brazil

August 11-14 2009

\footnotetext{
$1 \quad$ Speaker
} 


\section{Importance}

Outreach is informal education; it is the way most adults learn. So it must be diverse not only in content but in the way it is conveyed. I believe popularization must be taken seriously; it is a creative activity that should be carried out with passion.

Access to the Internet implies that information in general is available, so we must use this great resource, and, rethink about how to employ other tools in a meaningful way. Good web sites are necessary, especially if they are written in the local language and include examples from its culture. Information is neither knowledge nor experience; to better informal education one must emphasize different skills, such as selectivity, manual activities, curiosity and creativity.

When carrying out popularization one must preselect what is fundamental. It is hard to choose when there is too much to pick from. I believe people appreciate one's effort if our activities are kept intelligent, simple and short.

In my opinion a characteristic of a good outreach program includes knowing the public. The public should have a way to contact the spoke person; phone and email during live radio and television programs and time allocated for questions during public lectures and definitely during workshops. The public in general has a true curiosity about nature and sincerely wants to understand, and feels a sense of relief doing so.

I like to imagine outreach like a map. A map of Brazil is not the country but it comes in handy. So popularization is not science but it can be conveyed in such a way that it can transmit meaningful information, skepticism and a tool for decision-making.

The theory of evolution is an excellent example of an outreach topic to be addressed, because it shows a view of the world based on facts, logic and observation. Evolution explains and predicts how nature works.

I believe one should stress that science learns from mistakes. Astronomy is a magnificent tool for popularization due to the beauty of celestial objects, and the fascination of its scope.

\section{Creativity}

One of the focuses of formal education is learning rules. Teachers take great pain in showing how to behave at school, the way to write, treat pairs, what is important to know, etc. Unfortunately they tend to leave out creativity. This skill is the ability to connect concepts in new ways. Poets create new metaphors, painters colors and shapes, scientists discover new correlations and fundamental aspects about nature.

Due to outreach's freedom, it is ideal to show the way connections can be made between different sciences, we must keep in mind that astronomy is multidisciplinary by excellence.

I have personally included dance in my lectures. I have two different amateur companies that I can use upon request. One is a mambo group, its music is well known as supermarket music, but rarely danced due to is vigorous movements. I commissioned a mambo called “... and yet it moves” to honor Galileo. During the international year of planet earth the Institute of Geography at Mexico's National University took several sensitive seismographers to a large 
plaza and projected the graphs on giant screens. I gave a standard lecture on the Earth and then danced with my group to honor Galileo. After, I taught a few steps to the public. And then divided the crowd of several thousands in two groups so they could compete to cause the largest tremor by dancing mambo; the response was magnificent. I have danced in all the public lectures on Galileo I have given during the International Year of Astronomy. When I address the topic of Galileo's fame and mention, spacecrafts, monuments, bills, stamps I play the music and have people come up to the presidium and dance to honor this great scientist.

The other group I do outreach with dances ballet. I can use the ballerinas to help me with demonstrations and they can simulate constellations, rotating objects, story characters. Several physical laws can be explained using toe shows, and the simple dancing examples catch the audience's attention.

I have used the later group for telling stories and lives of great astronomers and will use them to explain cosmology. I believe this way of lecturing has been successful because science, ballet and classical music suffer from prejudice, the public feels they are beyond their reach. Explaining astronomy in a simple and intelligent way and dancing relieves tension and makes both science and art less threatening.

\section{Books and magazines}

A public lecture, a television or radio program are ideal for talking about recent scientific discovery; in the case the public wants to acquire knowledge further study is necessary. When one can express correctly in ones own language a scientific phenomenon we know it has been understood. So it is wise to provide books and magazines and good Internet sites references whenever one participates in a popularization activity in order to provide lasting understanding.

I have written several astronomy books for different levels. I usually take a few to distribute by tossing them at the audience. Since I am such a poor pitcher the printed materials are given out randomly. By the way, I also distribute Galileo scopes in this fashion and give out books and magazines for teacher to the organizers if the belong to a school.

During the last decades economist have being carrying out multidisciplinary research on happiness since its quest is the great motor for economic growth. Some of the results can be used for outreach. Two characteristics of happiness are its short time span and its relativity; hence its search never ceases. It has also been found that happiness can be achieved through family, friends, altruism, status, discovery and work.

Popularization should include items that lead to happiness like the pleasure of understanding, of conveying knowledge to others or even the status of attending a great workshop.

\section{Teachers}

Teachers should be treated with grate care. They can either be a multiplication of the science we convey or our enemies if they consider that topics such as intelligent design are true. Nevertheless it is interesting to mention that people can simultaneously live with several world concepts and depending on the circumstances applies the correct one. So during a science 
course they believe evolution is correct and at a family gathering where religion is an issue switch to creationism.

In my opinion one must write articles especially for teachers and participate in teacher training. In particular I have written for 15 years in the "Correo del Maestro". The original idea the editors had was that teachers would write about their work in the classroom. Unfortunately very few have submitted papers and instead scholars write on what they believe is interesting for good teaching. This publication is found on-line.

I find it difficult to conduct teacher training. Many students are over worked and taking lectures that they are not necessarily interested in, becomes a new burden. The training that has had greater success in Mexico is having a group of experts work at the school facilities with the teachers, that way they can discover what sort of help they need. When the experts stay at school till the teaching problem is solved. Unfortunately this procedure is slow, expensive and is not applied all over the country.

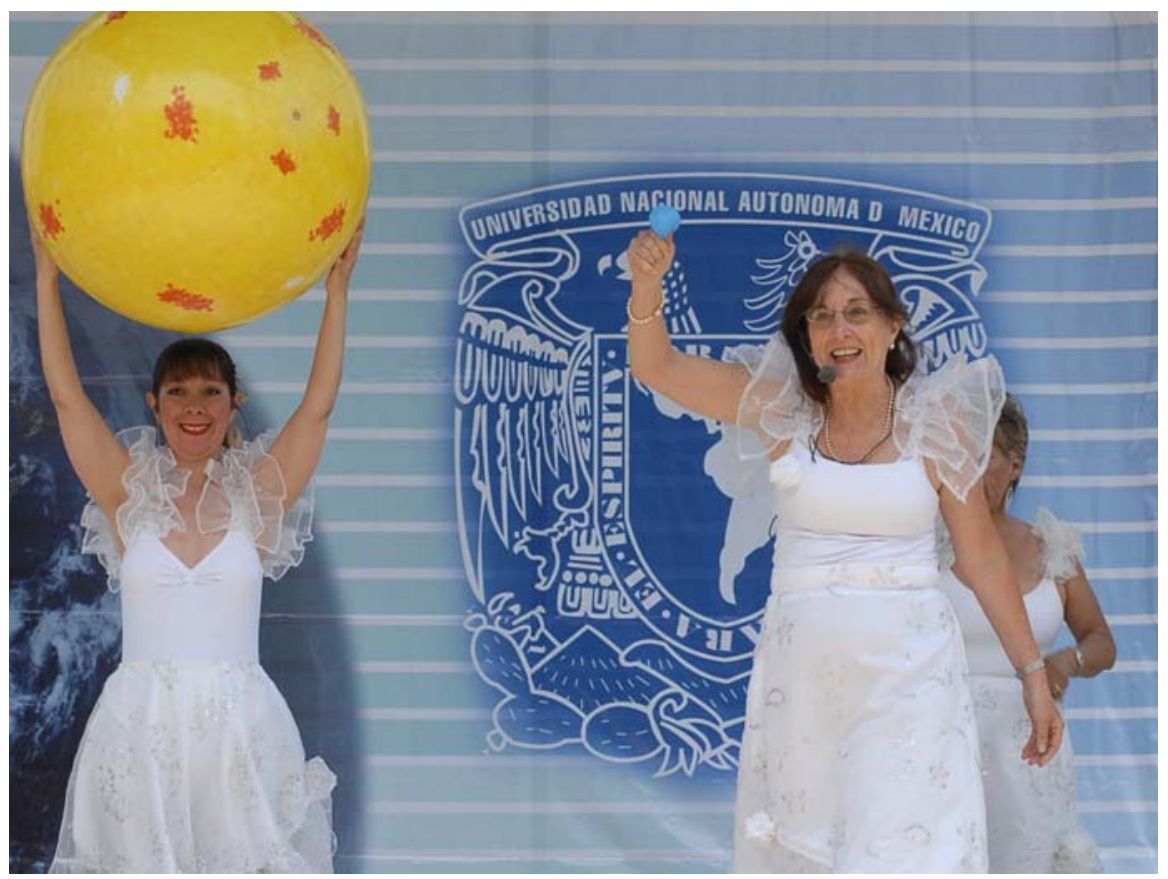

Figure 1: Use the local culture

\section{Assessment}

Assessment is necessary for all academic activities including popularization. As scientists we are well aware of the ways in which we are evaluated but for outreach new criteria are needed.

My experience has taught me that it is wise to invite a colleague in to my public performances and listen to his suggestions. And needless to say one must reciprocate.

It is not easy to select the proper referee. For instance when evaluating a text, some colleagues say it is all right without having carefully revised the manuscript and others tend to write it over again. Neither works. What I do is write a draft of let say a book and after ask a 
colleague to be a coauthor. This guarantees that he will look at the material carefully and bring in new ideas.

One of the most important things I have learned during my dance lessons is the way continuous assessment helps learning. During a ballet class mirrors, other students and the teacher's incessant scrutiny surround one. So whatever work we do it must be and is judged by others.

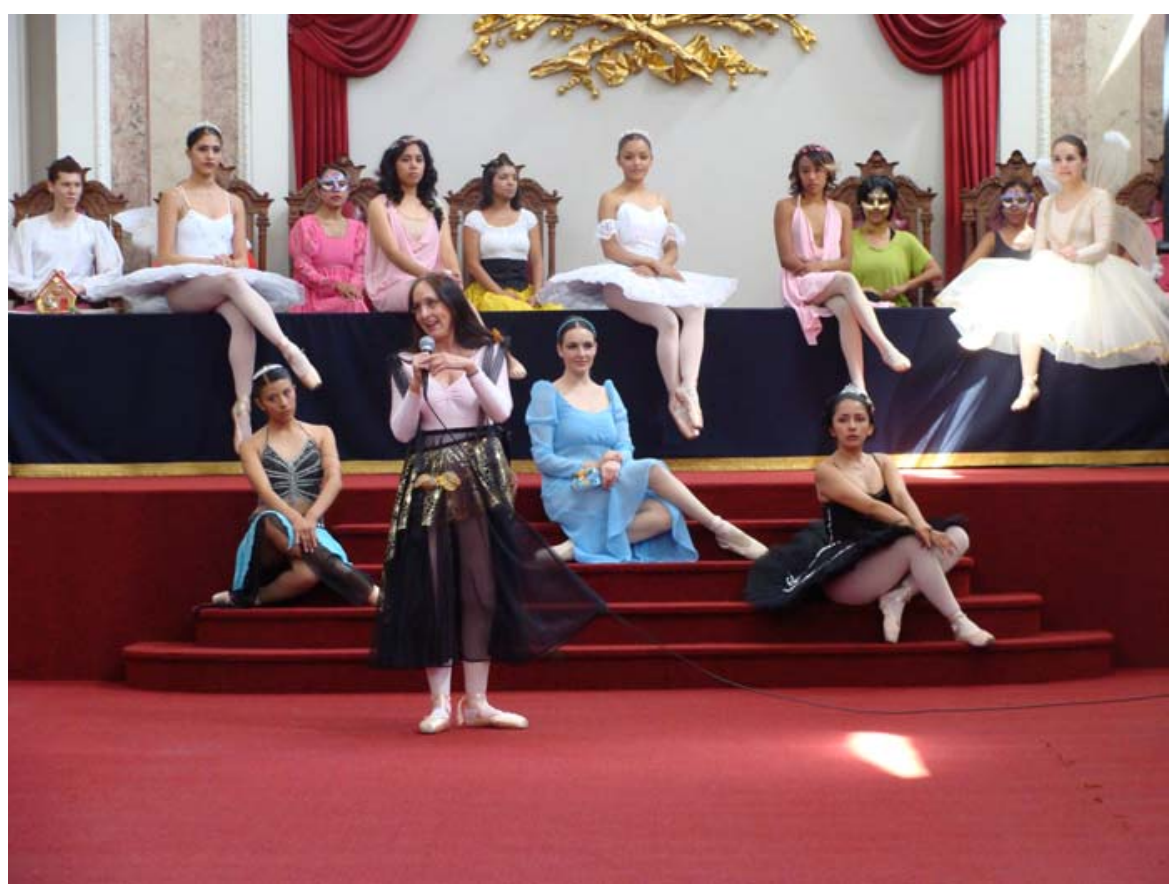

Figure 2

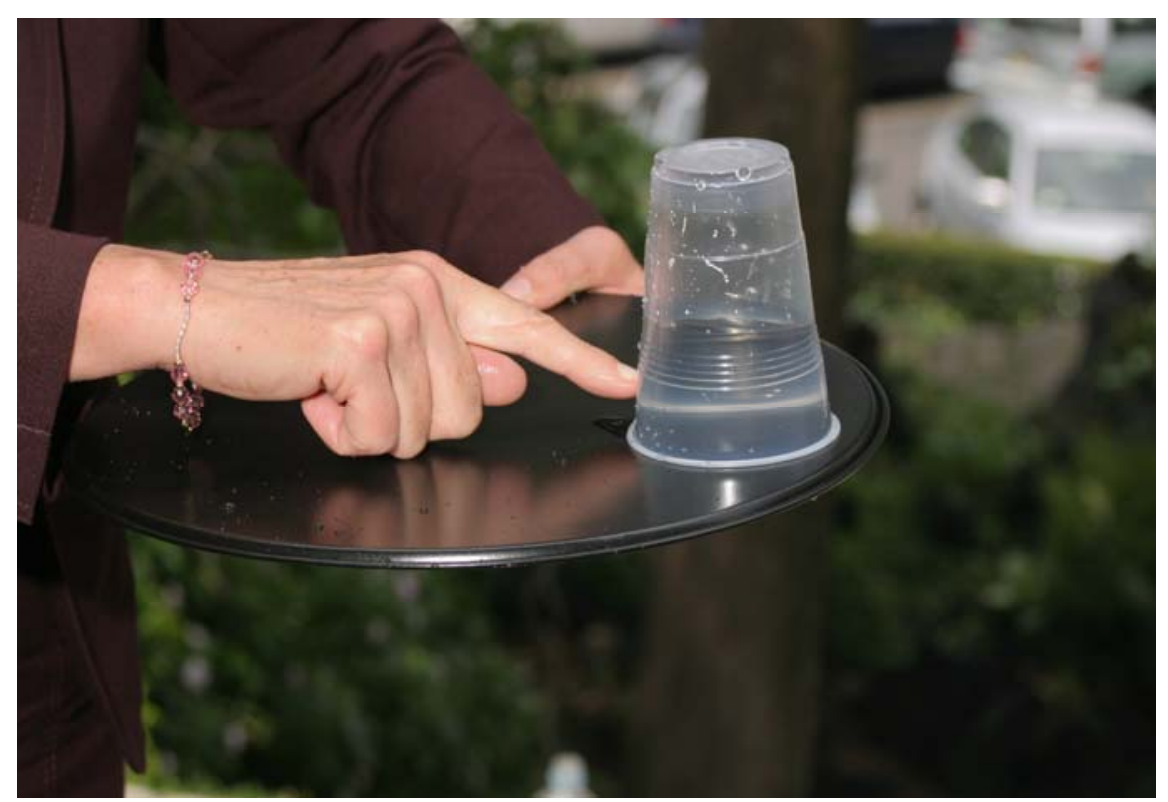

Figure 3 
It is important to create rules to evaluate outreach. Some are relatively simple, number of reprinted books, invitations to public lectures or TV programs. But for outreach these tend to measure popularity, not necessarily quality.

\section{Outreach at special settings}

There is a lot to carry out for popularization for children at hospitals. Several of the patients are tired, sad, bored and anxious. So an outreach program for them is a plus. In my experience if astronomy is included time keeping and small telescopes are ideal topics. Time is something the children have at large and they can usually handle galileoscopes with easy even if they are lying down. They also appreciate books, magazines and science television programs.

As with other activities outreach brings experience. Taking a small amount of risk can bring success. For instance by doing demonstrations on television one learns how to work with a camera person; and this comes in handy when giving lectures at mass events like those held in plazas or bullfight rings with audiences of tens of thousands watching giant screens and that are being broadcasted on national television.

When one is at loss as to how to handle a new project I believe the following items can come in handy. First, one must write down two lists, the reason is to focus on the project. The first one must include the formal purposes and the second one's personal goals. This seams an easy task but is important to keep it constantly in one's mind. Later on, one should pick the medium, TV, radio, web, museum, public lecture, article, book, workshop, and a play. And finally one must worry about funds. If one has good ideas and a convenient media to convey them, passion and work are what one needs to achieve the goal.

\section{My favorite demonstration}

I believe in hands-on activities done by the public are important during public lectures. The experiment I en enjoy the most doing is one on free fall. One needs a flat pan, a glass, water, and a flat surface covered with a towel. One has to fill the glass with water, cover it with the pan's flat surface, and turn the pan and glass upside down at the same time. Release the glass and move it to the edge of the pan. Stand next to the flat surface covered by the towel and pull the pan towards oneself swiftly and keeping it parallel to the ground. The glass and water will fall at the same time. For large crowds several this demonstrations should be carried out at the same time, at different places of the auditorium. This free fall experiment usually needs to be practiced, nevertheless I suggest the public should carry it out, even if the performer fails the first few times. Once they do it right it becomes a meaningful experience not only for the performer but also for the public. During this experiment one discovers one of the characteristics of science, its prediction capabilities.

I try to keep all my demonstrations simple and that can be done with materials people own, so their duplication is easy and teacher can repeat them in their classrooms. 


\section{Conclusion}

It is ideal to involve the public when carrying out a demonstration because it is easier remembered, especially if it surprising and makes people laugh.

Outreach has the advantage over formal education that it does not have some of its boundaries; one can work in freedom. Nevertheless it must be carried out with care. Popularization can be fun, and cannot replace formal education.

Being an outreach person bring great satisfactions. It offers a place for innovation, wonderful experiences and freedom.

\section{References}

[1] Antología de la divulgación de la Ciencia en México. Coordinadores: Juan Tonda, Ana María Sánchez y Nemesio Chávez. DGDC, UNAM, 2002.

[2] H. Domínguez \& J. Fierro, Albert Einstein: Un científico de nuestro tiempo. Editorial Lectorum, 2005 ISBN 970-32-1108-9.

[3] H. Domínguez y J. Fierro, La luz de las estrellas El Correo del Maestro, ediciones La Vasija, Junio 2006. ISBN 9707560959.

[4] H. Domínguez, \& J. Fierro, Isaac Newton. El Correo del Maestro Núm 128, pág. 11-14, Enero 2007.

[5] H. Domínguez, \& J. Fierro, Galileo para Maestros I El Correo del Maestro, Núm. 133, Pág 15-26, Año 12, Junio 2007.

[6] H. Domínguez, \& J. Fierro, Galileo para Maestros II El Correo del Maestro, Núm. 134, pág. 17-26, Año 12, 2007.

[7] H. Domínguez, \& J. Fierro, Galileo para Maestros III El Correo del Maestro, Núm. 135, pág. 10-18, Año 12, 2007.

[8] H. Domínguez, \& J. Fierro, Experimentos sobre la caída de los cuerpos El Correo del Maestro, Marzo 2008, Año 12 Número 142, pág. 5-12. ISSN 1405-3616.

[9] J. Fierro, textitLa duración de los años en los distintos mundos El Correo del Maestro, Núm. 50, p. 11, Julio, 2000.

[10] J. Fierro, La astronomía de México, Lectorum, 2001. ISBN 968-5270-55-4.

[11] J. Fierro, Volcanes en otros mundos, El correo del Maestro, Núm. 63, Agosto, 2001.

[12] J. Fierro, El Sol, la Luna y las Estrellas, DGDC, Colección Ciencia para Maestros, ISBN 970-32-1108-9, 2004.

[13] J. Fierro, Einstein para maestros, El Correo del Maestro, Año 9, Núm. 104, Enero, 2005.

[14] J. Fierro, ¿Cómo leer un texto de ciencia? El Correo del Maestro, Núm. 114, Noviembre 2005.

[15] J. Fierro, M. Espinosa, \& S. Torres, Una fiesta de estrellas, El Correo del Maestro, 2008, Año 13, Número 145, pág. 17-24. ISSN 1405-3616.

[16] J. Fierro, M.H. Monroy, \& V. Raya, Marte como planeta de roca, El Correo del Maestro, Año 100, Núm. 109, Junio, 2005. 
[17] J. Fierro, \& F. Nájera, ¿Cómo encontrar las constelaciones?, El correo del Maestro, Núm. 72, Mayo, 2002.

[18] J. Fierro, \& A. Sánchez, Conteos estelares y estimaciones matemáticas, El correo del Maestro, Núm. 82, Marzo, 2003.

[19] J. Fierro, \& A. Sánchez Valenzuela, Cartas Astrales, Un romance científico del tercer tipo Editorial Alfaguara 2006. ISBN 968-19-1175-X.

[20] I. Montero, \& J. Fierro, Leer y bailar. El Correo del Maestro, Núm. 117, pág. 5-15, Febrero 2006.

[21] L. Rayo, \& J. Fierro, La felicidad y la enseñanza Correo del Maestro, Marzo 2009, Año 13 Número 154, p. 22-30 ISSN 1405-3616.

[22] J. Spadaccini, J. Fierro, R. Paglierani, I. Hawkins, \& E. Cline, U úuchbenil le K'inó, Tradiciones del

[23] Sol, Traditions of the Sun, Libro trilingüe: Maya, Español, Inglés, NASA, 2006. 